Proc. Estonian Acad. Sci. Eng., 2006, 12, 4, 377-387

\title{
Study of surface fatigue of wear resistant powder metallurgical materials
}

\author{
Mart Saarna, Priit Kulu, Renno Veinthal and Riho Tarbe \\ Department of Materials Engineering, Tallinn University of Technology, Ehitajate tee 5, 19086 \\ Tallinn, Estonia; saarna@ staff.ttu.ee \\ Received 2 June 2006

\begin{abstract}
The problem of the fatigue strength of wear resistant materials is significant both from the theoretical and practical points of view. In abrasive wear, two different mechanisms of material removal occur either separately or simultaneously. At abrasion and low-angle abrasive erosion, microcutting is dominating and the main criterion for materials selection is hardness. At high-angle impact as well as at oblique impact by irreversible deformation, the exposed surface should be able to withstand repeated deformation, where low-cycle fatigue mechanism is dominating. The aim of this work was to determine and compare the surface fatigue behaviour of the high-tech powder metallurgical materials - PM/HIPed tool steels and conventional wear resistant steels. An attempt to find correlation between abrasive erosion and impact wear rates with materials surface fatigue resistance was made.
\end{abstract}

Key words: powder materials, wear, erosion, surface fatigue.

\section{INTRODUCTION}

Wear resistant materials, particularly powder metallurgical (PM) materials containing pores, defects or inhomogeneities are classified as so-called "structurally brittle" materials and their behaviour at different wear conditions may be unpredictable. High surface hardness of traditional materials does not always provide the wear resistance required for faultless operation of machine parts and tools under the conditions of erosion and impact wear. Removal of material in wear caused by impact and cyclic loading and high contact pressure occurs as a result of direct fracture or fatigue processes. Thus, toughness and fatigue properties of materials are as important as their hardness parameters.

It is well known that there is a substantial difference between ductile and brittle materials when the weight loss in erosion is measured as a function of the impact 
angle. Ceramic materials are considered to be capable of reducing scratching and micromachining type surface damage when exposed to low-angle impacting particles due to their high hardness and stiffness. At high angle of impact, the exposed surface should be able to withstand repeated deformation. More elastic materials, such as steels, are usually preferred to cermets where cracks propagate rapidly and lead to material removal. With mixed abrasive erosion and impact wear, where a wide range of impact angles are applied, there is a controversy between material hardness and fracture toughness in the formation of wear resistance. Composite materials, especially reinforced metal-matrix composites and so called "double cemented" metal-matrix structures allow a partial solution of this problem [ $\left.{ }^{1}\right]$.

If material hardness exceeds that of the abrasive, erodent particles can hardly cause plastic flow in the hard target. The degree of elastic penetration and therefore the energy transmitted to a surface depends on the elasticity modulus. If it is high, less elastic penetration occurs. Therefore, as compared to abrasive hardness, the modulus of elasticity is one of the most important parameters influencing the wear resistance in the case of harder materials $\left[{ }^{2}\right]$. Under these conditions, particle impacts may cause a low-cycle fatigue failure of the reinforced metal-matrix and hard phase particles.

If the hardness of the abrasive exceeds that of the wearing material, the following processes take place: penetration of erodent particles into the material surface, microcutting or ploughing and failure of hard phase particles resulting in the detachment of small chips. Since the erosion of brittle grains is primarily caused by a mechanism involving the initiation and propagation of microcracks, one expects that the fracture toughness of the material influences the erosion rate. The toughness-hardness map of wear resistant materials proposed in $\left[{ }^{3}\right]$ is shown in Fig. 1. The wear of materials with low fracture toughness (below $10 \mathrm{MPa} \cdot \mathrm{m}^{0.5}$ by silica erodent) is caused mainly by brittle fracture, while the wear of materials with low hardness (less than abrasive hardness) is caused mainly by microcutting. At higher hardness and fracture toughness values, surface fatigue is dominating.

Depending on the intensity of the impact processes, the contact can lead to reversible or irreversible deformation in the surface area of the basic body. The reversible impact process generates in the target surface layer only stresses, which lie below the yield strength. Consequently, they are of elastic nature. Due to the elastic deformation, material removal can be caused by fatigue. Nevertheless, this wear component in abrasive erosion is many times lower than that caused by irreversible deformations in impact wear. The process of material removal starts after a relatively low deformation, i.e. at a small number of contacts between abrasive particles and the target.

Attempts to correlate the erosion rates of brittle materials with the parameters of the materials were made in $\left[{ }^{3,4}\right]$. In the proposed models, hardness and fracture toughness emerge as the main material parameters that control erosion. High hardness increases the resistance to plastic deformation while high fracture toughness increases the resistance to fracture. Thus, in abrasive wear, one of the mechanisms of material removal is surface fatigue wear. 


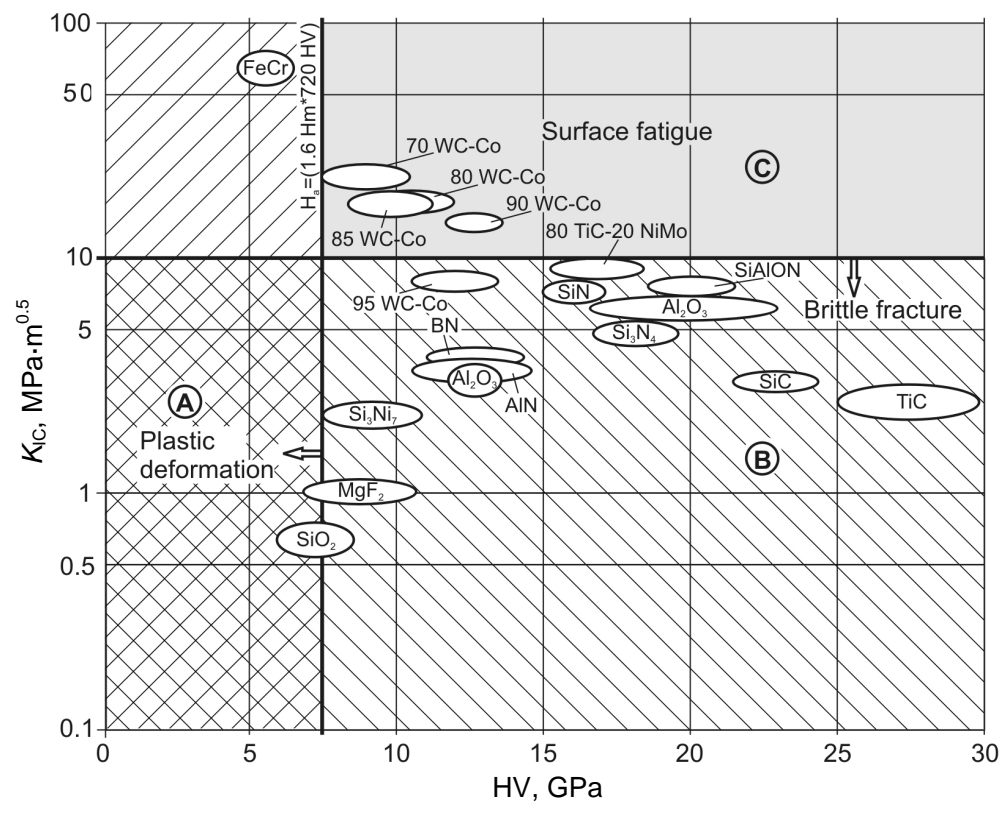

Fig. 1. Erosion wear map of wear resistant materials $\left[{ }^{3}\right] ; K_{\mathrm{IC}}-$ fracture toughness.

Fatigue performance of wear resistant materials under cyclic loading and at monotonic loads has been studied in several papers $\left[{ }^{5,6}\right]$. It has been found that the adhesive wear fracture and fatigue start similarly - predominantly in the binder phase (extrusion-intrusion mechanism), in contrast to abrasive erosion and sliding wear $\left[{ }^{5}\right]$. To test the surface fatigue properties of wear resistant materials, a new test system has been constructed $\left[^{6}\right]$. The results were presented as wear resistance maps (relationship between surface fatigue wear and specific energy of scratching) of the tested materials (Hadfield steel and Hardox steel) and the relative wear resistance of different materials were compared.

This paper studies the surface fatigue behaviour of powder metallurgical materials in different groups of wear resistant materials and looks for eventual relation between wear resistance and surface fatigue properties.

\section{EXPERIMENTAL}

\subsection{Studied materials}

The studied materials include PM materials and conventional steels (Table 1). These materials are commonly used in many applications where resistance to abrasive-erosive wear or impact wear is required. The microstructure of PM materials is presented in Fig. 2. 
Table 1. Structure and hardness of the studied materials

\begin{tabular}{|c|c|c|c|}
\hline Material & Structure & $\begin{array}{l}\text { Density, } \\
{\mathrm{g} / \mathrm{cm}^{3}}^{3}\end{array}$ & Hardness \\
\hline \multicolumn{4}{|l|}{ Powder materials: } \\
\hline MMC & $\begin{array}{l}\text { PM/HIPed }(\text { Cr-steel + VC) + WC, reinforcements: } \\
\sim 20 \% \text { VC }(d \sim 1 \mu \mathrm{m}) \text { and } \sim 20 \% \text { WC }(200-300 \mu \mathrm{m})\end{array}$ & 9.9 & $550 / 1540 \mathrm{HV}$ \\
\hline Weartec $^{\circledR}$ & Spray formed/HIPed high speed steel, fine grained & 7.3 & $60 \mathrm{HRC}$ \\
\hline \multicolumn{4}{|c|}{ Conventional steels: } \\
\hline Hadfield steel & Austenite & 7.8 & 180-220 HBW \\
\hline Hardox 400 & Martensite + troostite & 7.8 & 380-410 HBW \\
\hline
\end{tabular}
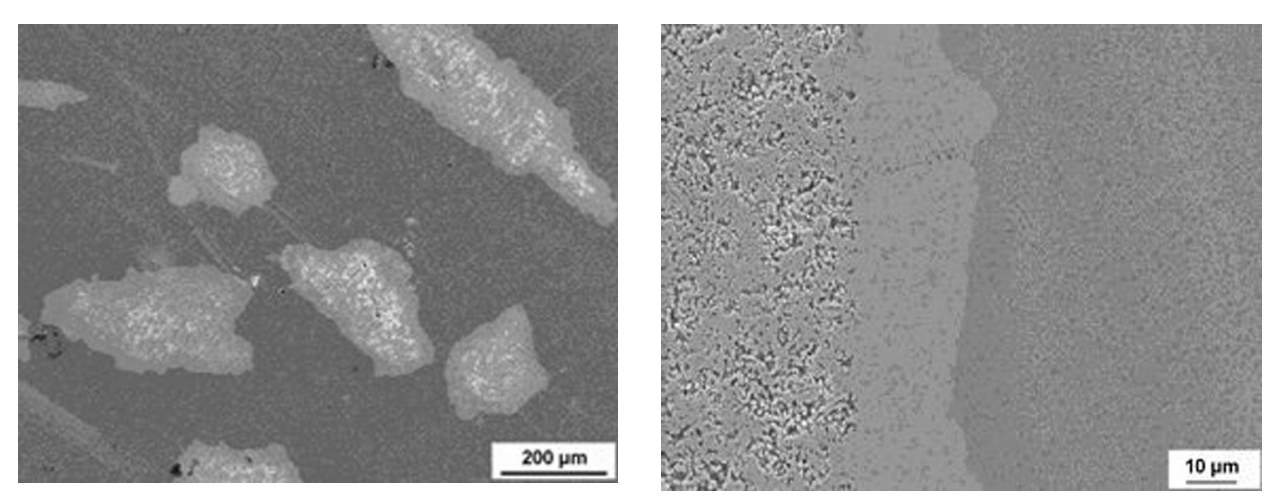

(a)
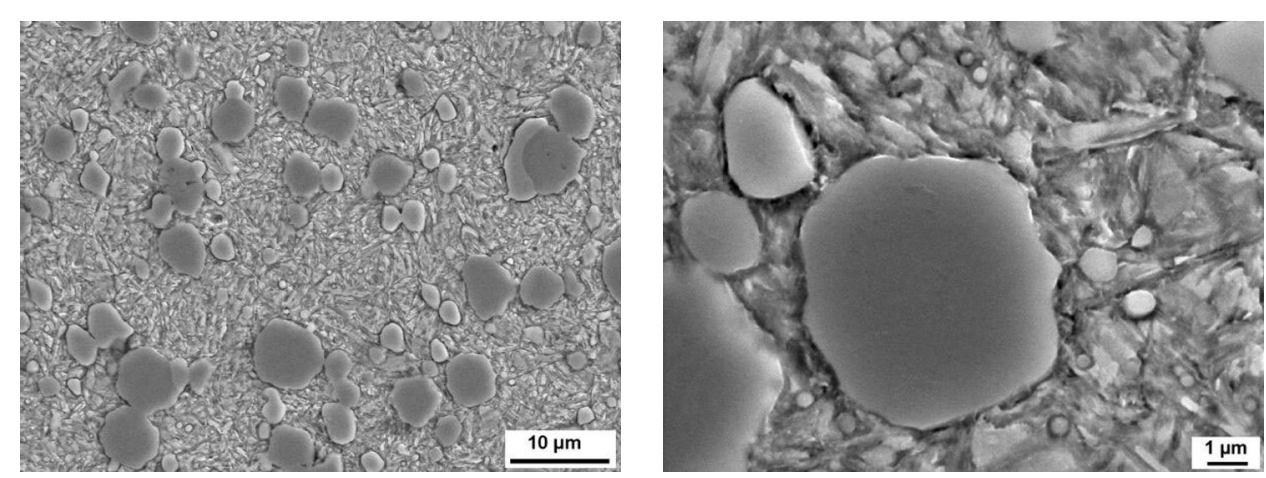

(b)

Fig. 2. Microstructure of the studied powder materials at different magnifications: (a) MMC; (b) Weartec ${ }^{\circledR}$.

\subsection{Surface fatigue testing}

To study surface fatigue wear (SFW), the test system developed at Tampere University of Technology was used. The system produces repeated stresses on the material surface (Fig. 3) $\left.{ }^{6}\right]$. It consists of a servohydraulic materials testing 


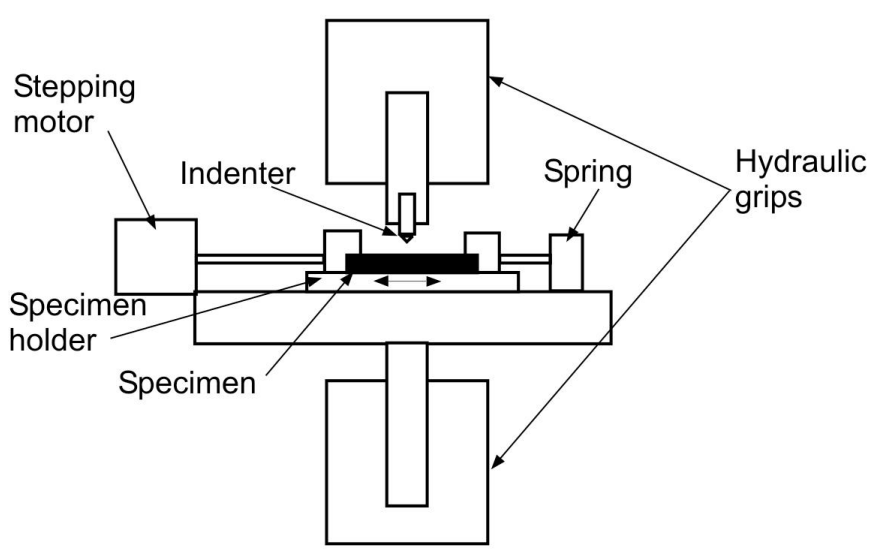

Fig. 3. The SFW test scheme.

machine Instron 8800, an indentor, a special specimen holder, and a base plate. The indenter was a hardmetal cone with tip angle of $120^{\circ}$ and radius of $350 \mu \mathrm{m}$. The test procedure was straightforward: after each indentation, the specimen was moved by a distance of $400 \mu \mathrm{m}$ to cover an area of $6 \times 6 \mathrm{~mm}$ with a regular rectangular pattern. At pattern testing, 30000 cycles with the normal load of $1500 \mathrm{~N}$ were used to produce surface fatigue wear in the studied materials. To study the wear mechanism in surface fatigue, a repetitive single point loading with normal load of $1500 \mathrm{~N}$ was also used.

\section{RESULTS AND DISCUSSION}

\subsection{Surface fatigue wear}

The results of the SFW test of PM materials and conventional steels were quantified by measuring the mass loss after the test. The fatigue wear behaviour of the studied materials was characterized by mass loss and volumetric wear in $\mathrm{mm}^{3}$. However, the mass losses that occur during the SFW test are inversely proportional to the SFW resistance of the material and the quantitative assessment of the SFW resistance is complicated. The results of SFW tests (average of at least two tests) are given in Table 2.

Table 2. Surface fatigue wear of materials; pattern testing by 30000 cycles with the load of $1500 \mathrm{~N}$

\begin{tabular}{l|c|c}
\hline \multicolumn{1}{c|}{ Material } & Mass loss, $\mathrm{mg}$ & Volume wear, $\mathrm{mm}^{3}$ \\
\hline MMC & 290.9 & 29.4 \\
Weartec ${ }^{3}$ & 5.3 & 0.7 \\
Hadfield steel & 17.9 & 2.3 \\
Hardox 400 steel & 17.8 & 2.3
\end{tabular}



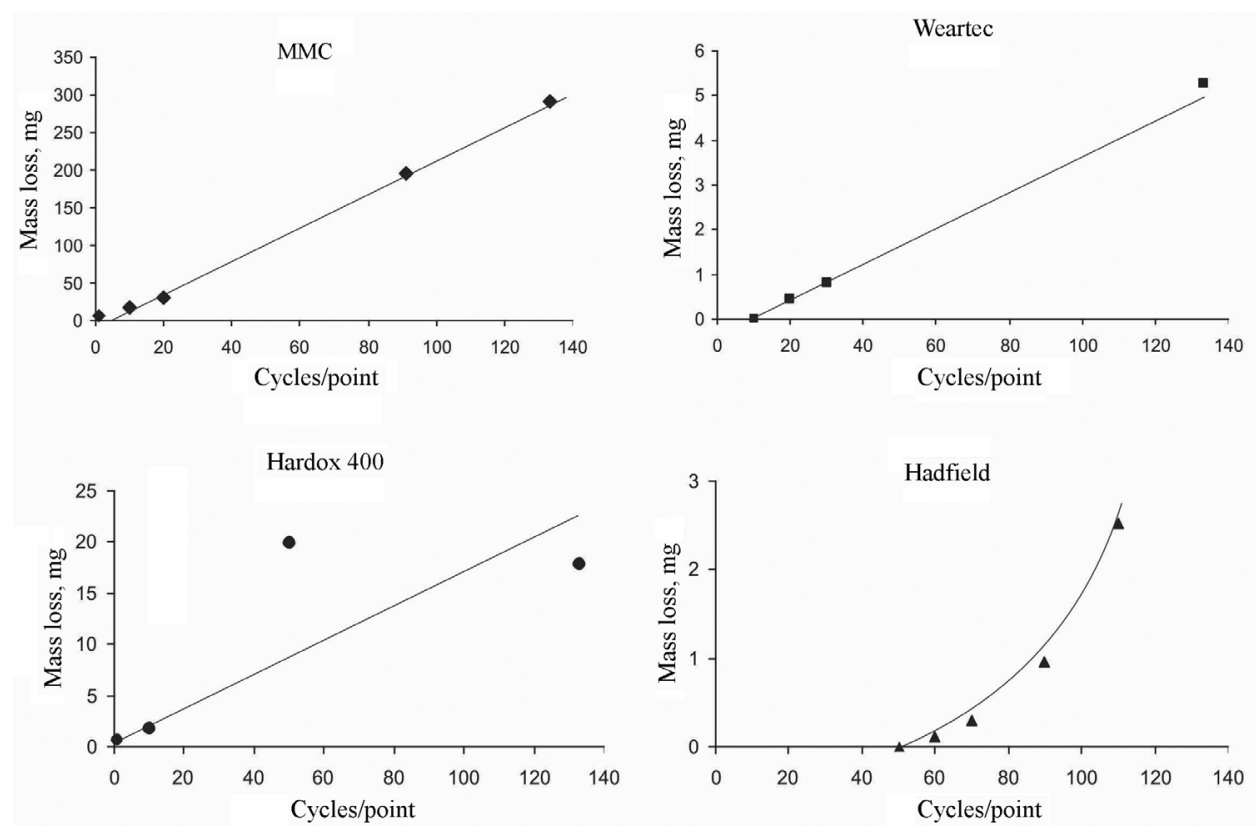

Fig. 4. Dependence of SFW on the number of loading cycles.

The dependence of SFW on the number of cycles $N$ per a single point is given in Fig. 4. As it follows from Fig. 4, in the case of PM materials (MMC and Weartec), the fracture starts after a single loading and the removal of the material occurs already at a low number of loading cycles (in our studies at $N \geq 10$ ). At the same time, for the well-known wear resistant Hadfield steel the removal of the material starts when $N \geq 50$.

To explore the eventual correlation between abrasive wear resistance and surface fatigue resistance, the abrasive erosion wear (AEW) and abrasive impact wear (AIW) resistance of the studied materials were determined. The volumetric wear rate in $\mathrm{mm}^{3} / \mathrm{kg}$ at $\mathrm{AEW}$ was determined with the centrifugal accelerator CAK-5 at the velocity of $80 \mathrm{~m} / \mathrm{s}$ and impact angle of $90^{\circ}$ with quartz sand (particle size from 0.1 to $0.3 \mathrm{~mm}$ ). In the case of AIW, the wear rate was determined with an experimental impact tester DESI at the velocity of about $60 \mathrm{~m} / \mathrm{s}$ and impact angle of about $90^{\circ}$ with granite gravel (particle size from 4 to $5.6 \mathrm{~mm}$ ). The relative wear resistance $\varepsilon_{v}$ was calculated as the ratio of the volumetric wear rates of the reference material (steel $0.45 \% \mathrm{C}$ ) and the studied material. The wear resistance of the studied materials at abrasive erosion and the abrasive impact wear are given in Table 3.

To study the eventual correlation between AIW-SFW and AEW-SFW test results, the corresponding wear maps were plotted (Fig. 5). The relative wear resistance of tested materials is higher in the case of AIW when compared to AEW. MMC has the best relative wear resistance in both cases despite of having 
Table 3. Abrasive erosion wear and abrasive impact wear resistance of the studied materials

\begin{tabular}{l|c|c|c|c}
\hline \multirow{2}{*}{ Material } & \multicolumn{4}{|c}{ Wear resistance } \\
\cline { 2 - 5 } & \multicolumn{2}{|c|}{$\mathrm{AEW}, a=90^{\circ}$} & \multicolumn{2}{c}{$\mathrm{AIW}, a=90^{\circ}$} \\
\cline { 2 - 5 } & $\mathrm{mm}^{3} / \mathrm{kg}$ & $\varepsilon_{v}$ & $\mathrm{~mm}^{3} / \mathrm{kg}$ & $\varepsilon_{v}$ \\
\hline MMC & 19.3 & 1.6 & 10.4 & 2.6 \\
Weartec ${ }^{\circ}$ & 30.1 & 1.1 & 11.4 & 2.3 \\
Steel 45 & 31.5 & 1.0 & 26.6 & 1.0 \\
Hadfield steel & 35.8 & 0.9 & 20.2 & 1.3 \\
Hardox 400 steel & 26.2 & 1.2 & - & -
\end{tabular}

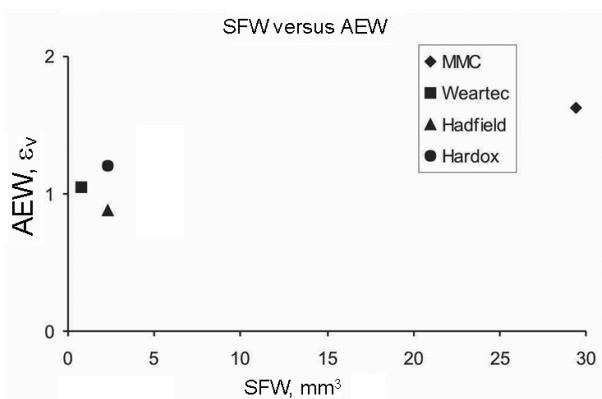

(a)

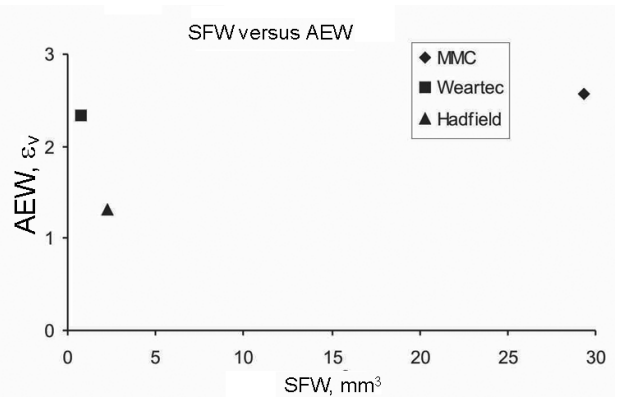

(b)

Fig. 5. Dependence of AEW and AIW on SFW.

the poorest SFW test results. The high AIW resistance of Weartec is in correlation with SFW test results (Weartec ${ }^{\circledR}$ demonstrated the best results in SFW).

\subsection{Wear mechanisms}

To reveal the material behaviour under the conditions of SFW, a SEM study on the worn surfaces was conducted. The wear surfaces of the MMC material and Weartec ${ }^{\circledR}$ were studied by using SEM JEOL-840A. Examples of the results are given in Figs. 6 and 7.

Under the conditions of SFW, the mass loss of Weartec ${ }^{\circledR}$ was the least and the mass loss of MMC was the highest, exceeding the others significantly. The SEM images shown in Figs. 6 and 7 explain the reasons of such behaviour. Large carbides have fractured after single or low number of indentations, and cracks in the binder appear along the indentation perimeter as well as in hard and binder interface phases. As a result, splinters or even whole carbide particles are removed from the contact zone. This implies that in the case of SFW, the used load was too high causing direct fracture and separation of the hard phase and cracking of the binder (Fig. 6). The matrix phase of MMC is also susceptible to fatigue: the cracks, emanating from the binder, can be observed at a high number of indentations (Fig. 6a). Weartec ${ }^{\circledR}$, consisting only of small vanadium carbide 

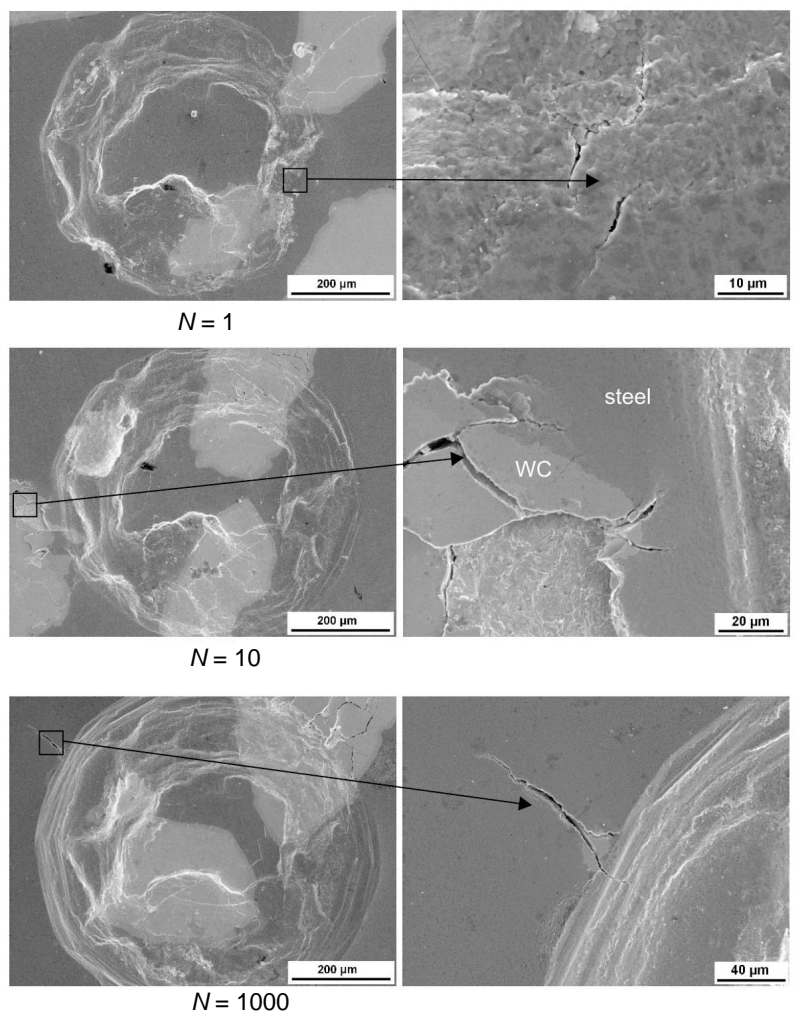

(a)

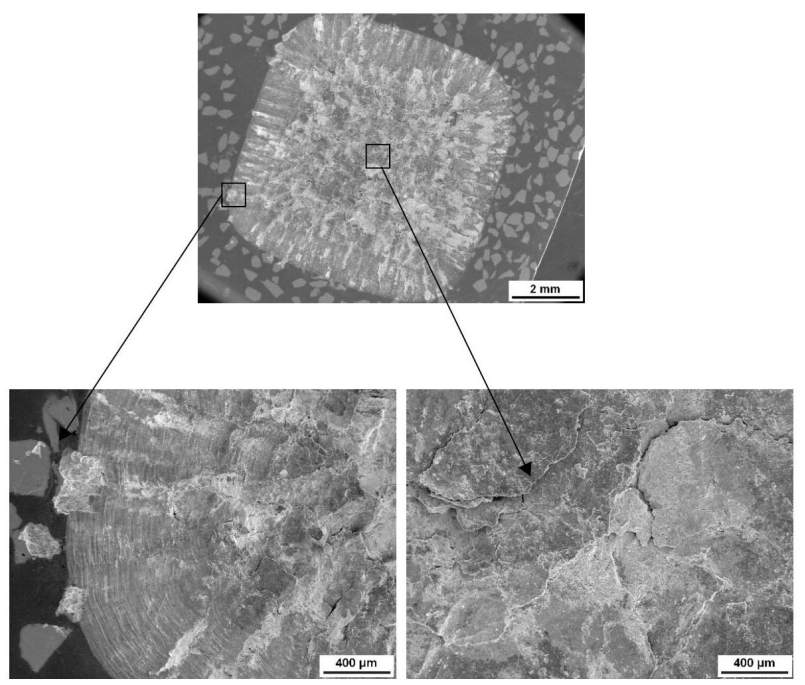

(b)

Fig. 6. SFW indents of MMC: (a) single point loading, normal load $1500 \mathrm{~N}$; (b) pattern loading, normal load $1500 \mathrm{~N}$ on $6 \times 6 \mathrm{~mm}, N=30000$. 

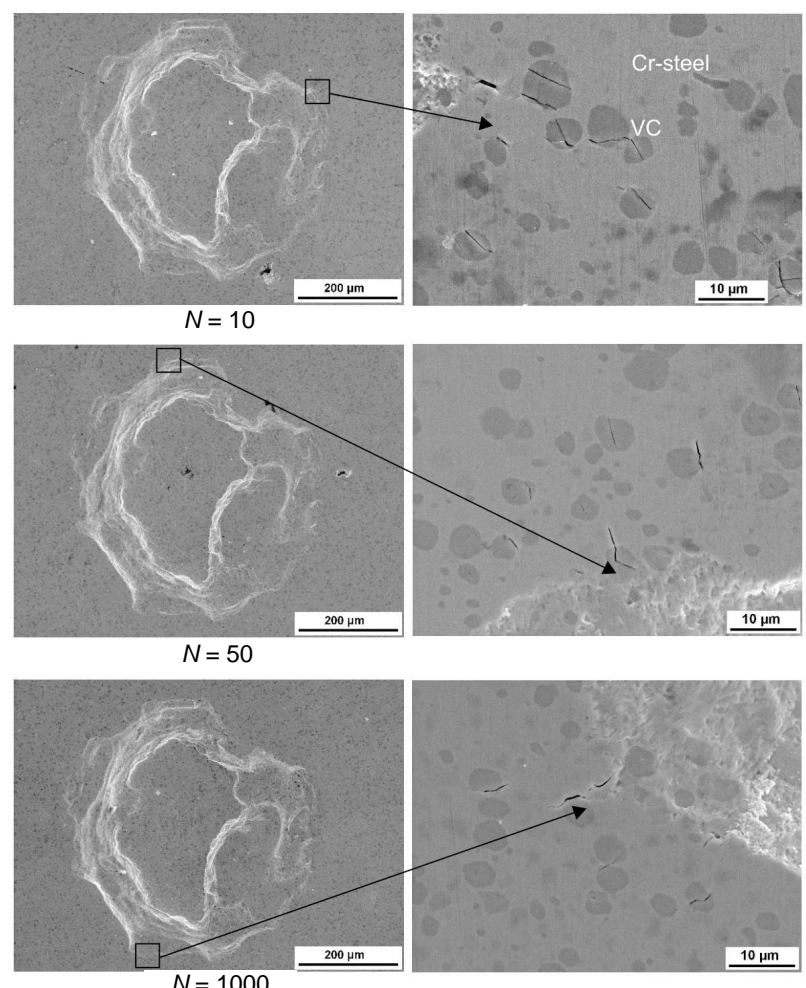

(a)

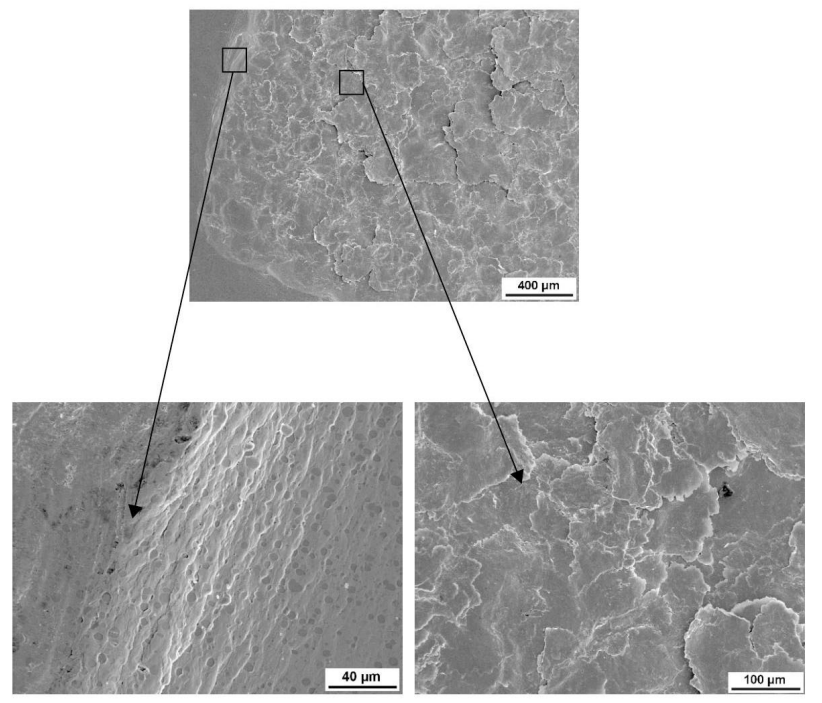

(b)

Fig. 7. SFW indents of Weartec ${ }^{\circledR}$ : (a) single point loading, normal load $1500 \mathrm{~N}$; (b) pattern loading, normal load $1500 \mathrm{~N}$ on $6 \times 6 \mathrm{~mm}, N=30000$. 
particles as reinforcement (Fig. 2b), is not as sensitive to SFW as MMC. Although cracks can be seen on the SEM micrographs of indentations, they start to appear in a much later stage of the testing. These cracks appear mostly first in the VC phase, propagating later to the matrix (Fig. 7a). In addition to the cracks perpendicular to the surface, cracks parallel to the material surface appear. Eventually, this will lead to the formation of chips and lamellas, which are removed from the surface (Fig. $7 b$ ).

\section{CONCLUSIONS}

Surface fatigue wear tests of PM materials, performed by both pattern and repetitive single point loading, demonstrated the complexity of the quantitative assessment of the surface fatigue wear resistance of PM materials. The results of surface fatigue wear tests revealed that in contrast to the abrasive erosion and impact wear, the surface fatigue wear of PM materials starts in the harder phase with fracture occurring after a single or low number of loading cycles. In the case of reinforced metal-matrix composite materials, cracking and separation of harder phase plays a significant role in surface fatigue resistance. In contrast to the traditional wear resistant Hadfield steel, the surface fatigue wear of a MMC material starts after considerably lower number of loading cycles.

The results of abrasive erosion and impact wear tests seem to correlate for both PM materials and conventional wear resistant steels. No correlation was found between the abrasive erosion or abrasive impact wear resistance and the surface fatigue wear resistance of powder materials.

\section{ACKNOWLEDGEMENTS}

The authors are grateful to Prof. V. T. Kuokkala and MSc. M. Hokka from Tampere University of Technology for providing the opportunity to conduct the surface fatigue tests, and to Metso Powdermet for helpful cooperation. This work was supported by the Estonian Science Foundation (grant No. 5581).

\section{REFERENCES}

1. Kulu, P. Selection of powder coatings for extreme erosion wear conditions Adv. Eng. Mater., 2002, 4, 392-397.

2. Kleis, I. and Kulu, P. Solid Particle Erosion. Occurrence, Prognostification and Control. Tallinn University of Technology Press, Tallinn, 2005.

3. Veinthal, R. Characterization and Modelling of Erosion Wear of Powder Composite Materials and Coatings. Thesis. TUT, Tallinn, 2005.

4. Veinthal, R., Kulu, P. and Käerdi, H. Characterization of the structure of composite powder materials and coatings. Mater. Sci. (Medžiagotyra), 2005, 11, 376-380. 
5. Preis, I. Fatigue Performance and Mechanical Reliability of Cemented Carbides. Thesis. TUT, Tallinn, 2004.

6. Hokka, M., Kuokkala, V.-T., Siitonen, P. and Liimatainen, J. Experimental techniques for studying the behaviour of wear resistant materials under dynamic gouging and surface fatigue. In Proc. ICEM12-12th International Conference on Experimental Mechanics. Bari, 2004 (CD ROM).

\title{
Kulumiskindlate pulbermaterjalide pinnaväsimuse uurimine
}

\author{
Mart Saarna, Priit Kulu, Renno Veinthal ja Riho Tarbe
}

Kulumiskindlate materjalide pinnaväsimus on oluline nii materjalide omaduste hindamise kui ka nende kasutamise seisukohalt. Abrasiivkulumise tingimustes toimub materjali eemaldamine kahe erineva mehhanismi kohaselt. Abrasiiv-erosioonkulumisel väikestel kohtumisnurkadel on domineeriv materjali eemaldamine mikrolõikamise teel ja materjali valiku põhikriteeriumiks on kõvadus. Normaal- ja kalderosioonil peab kulutatav pind taluma pöördumatuid korduvaid deformatsioone ja domineeriv on materjali järkjärguline eemaldamine vähetsüklilise väsimuse tagajärjel. Artikli eesmärgiks on määrata ja võrrelda kõrgtehnoloogilise pulbermetallurgia kuumisostaat-pressimise teel saadud kulumiskindlate tööriista- ja tavateraste pinnaväsimusomadusi. Samuti on püütud leida seoseid katsetatud teraste abrasiiv-erosioon- ning löökkulumise ja pinnaväsimuse vahel. 